\title{
HISTOPATHOLOGIC AND IMMUNOHISTOPATHOLOGIC EVALUATION OF PITYRIASIS ROSEA
}

\author{
By \\ Gamil, T.; Abdulhamid, A. Rizk, \\ A. Sharara, L. and Darwish, N. \\ From \\ Pathology and Dermato/ogy Departments, \\ Mansoura and Alazhar Universities \\ Received for puplication : 7/7/1991
}

\section{INTRODUCTION}

Pityriasis rosea (PR) is a common self-limited dermatological disorder. It appears to be a non specific cutaneous reaction pattern with a large number of causes. Still, the etiology and pathogenesis of such trouble are obscure, (Bos et al., 1985). Infections etiology, mostly viral has been suggested, although there is no direct evidences that support this hypothesis. Current evidence indicates that a cell mediated immune mechanism may be implicated in the pathogenesis of PR, (Parsons, 1986).

Histopathologic studies indicated the presence of eczematous changes in an early phase and parapsoriasis 109 enplaquelike changes in the late phase (Panizzon \& Bloch, 1982). Ultrastructurally, the presence of cytolytic degeneration of Keratinocytes adjacent to Langerhans cells and dyskeratotic cells were recognized in the epidermis (Sugiura et al., 1988). Takaki et al., (1977) demonstrated significant rise in $\operatorname{lgM}$ in the patient's serum, while Mobacken et al., (1983) failed to disclose any such antibodies or immunocomplexes. In Contrast with the investigations about the possible participation of humoral immunity in the pathogenesis of PR, a little attempt has been made to analyse the cellular immunity of such disease.

Here in we describe the histopathMANSOURA MEDICAL JOURNAL 
ological and the immunohistopathologic characteristics of secondary skin lesions of PR by immunophenotyping the inflammatory cells in situ using monoclonal antibodies that mainly define leukocyctes and monocytes in order to understand the pathomechanism of such trouble.

\section{MATERIAL AND METHODS}

The histopathologic and immunohistopathologic characteristics of the disease were carried on the lesions from 20 patients with PR. They were selected from the outpatient's clinics of Dermatology at Mansoura and Alazhar Universities. They were $14 \mathrm{fe}$ males and 6 males. Their age ranged between $18-55$ years. The diagnosis of PR was based clinically on the presence of typical skin lesions such as single herald patch followed by secondary disseminated eruption (Christmas tree) lasting about 3-8 weeks. Punch biopsy specimens were obtained from secondary eruptions under local anaesthesia. All biopsis were immediately fixed for $2 \mathrm{hs}$ in $\mathrm{BS}$, a fixative composed of mercuric chloride and formaldehyde, and afterwards kept in methanol until further processing. After paraffin embedding, semi-serial sections were cut and used for routine HX. \& E. staining and immunohistochemistry. The immunohistochemical method performed using indirect peroxidase i.e. peroxidase anti-peroxidase PAP technique, (Naeim et al., 1982). the following monoclonal antibodies were used:

1- $\mathrm{MB}_{2}$ (Biotest Seralo, Brussels, Belgium), directed against $B$ cells.

2- MT2 (Biotest Seralo), recognizing all mature $T$ and $B$ lymphocytes.

3- $\mathrm{LN}_{2}$ (Biotest Seralo), recognizing $B$ cells and histiocytes.

4- LC (Biotest Seralo), recognizing all lymphocytes and macrophages.

5- Mac 337 (Dakopatts, Copenhagen, Denmark), directed against macrophages and infiltrating histiocytes. 
N. B. The antibodies were kindely supplied by Dr. K. Geboes Professor of Pathology Leuven University, Belgium.

\section{RESULTS \\ 1- HISTOPATHOLOGICAL}

The histopathological study was performed in order to confirm the clinicai diagnosis. There were parakeratosis, Decreased granular layer, Acanthosis, spongiosis, Hydropic degeneration of basal cells, papillary edema, superficial perivascular infiltration containing histiocyte like cells, pigmentary incontinence and the presence of eosinophilic bodied in the upper dermis. Not all these data are found in each case, but they are collectively shown in all cases.

\section{2- IMMUNOHISTOPATHOLOGY}

Biopsoes from all patients (20 cases) present positive data in only 13 cases. The remaining 7 cases show negative results for all the stained monoclones. Also, not all the monoclones were positive in all the 13 stained cases.
1- $\mathrm{MB}_{2}$ intense positive cells were seen in the dermal infiltrate, in all the stained cases (13 cases).

2- MT2 positive cells with moderate intensity were seen in the cells membrane of both $T$ \& $B$ lymphocytes in 10 cases only.

3- $\mathrm{LN}_{2}$ positive cells were found in the infiltrate. This stain was positive in 9 cases.

4- LC showed positive cells (all lymphocytes and macrophages) in all the stained cases (13 cases).

5- Mac 387 positive cells were seen in the infiltrate in the 13 cases.

\section{DISCUSSION}

The etiology of this self limited papulosquamous dermatosis still remains unclear. Although several clinical features suggest an infections cause, yet no pathogenic micro-organism has so far been isolated.

In spite of our described histopathological findings, there were failure to disclose:

MANSOURA MEDICAL JOURNAL 
1- Dyskeratosis, a point that contradicts the finding of Aoshima et al., 1981 \& El-Shiemy et- al., (1987) who cosidered that dyskeratosis is tha most conspicuous finding in PR and these dyskeratotic cells show ultrastructural changes indicating viral etiology (such viral etiology was denied by Langs, 1988 who stated that in patients with PR the serum interferon was not elevated).

2- Epidermotropism, a point that not agree the concept of Bos et al., (1985) who suggeseted that the presence of epidermotropism with interaction between mononuclear cells and the epidermal component is of importance in the pathogenesis of PR.

These histopathologic differences may be authenic but on the other hand it may be due to technical factors (changes in the fixative used) or lesional variability.

Volume 21, 1991
There has been no definite evidence that implicate any immunologic process in PR. Our immunohistopathologic studies using monoclonal antibodies disclosed the presence of $T$ lymphocytes, B-lymphocytes and macrophages or monocytes in secondary PR lesions in 13 patients only. Not all cases gave positive data. This may be due to technical factors such as the use of fixed or unfixed tissue. Still, such immunologic behaviour was variable in different cases. This variability may depend on the degree of lesiciat changes. In addition, the expressio of Mac 387 positive cells together with their patchy distribution accumulating in relation to the vascular spaces in the affected area is an argument in favour of their myelomonocytic origin and these cells can be stimulated by such disease, these findings are in agreement with Abia and Tagami (1985).

Although these data suggest an important role that may be played by cellular immune reaction occuring in PR lesions and also support the findings of Abia and Tagami (1985), and 
Parsons (1986), yet there are many suggestions that the skin is a particular environment for T-cell differentiation and that the presence of such cells in the skin lesions was not a particular phenomenon (Haynes et al., 1982 and Patterson \& Edelson, 1983). By this study, we have gained some information about the in situ immunologic charcterization of the lesional skin of PR. However, still we need further immunologic information about the peripheral blood lymphocytes, lesional T-subsets and those in primary herald patch to clarify the whole immune pathomechanism involved in PR.

\section{ABSTACT}

Biopsy specimens of secondary skin lesions of PR obtained from 20 patients were studied histopathologically and immunohistopathologically (using monoclonal antibodies directed against the dermal inflammatory infiltrate). The tissue was paraffin embedded after fixation in BS and methanol. 13 cases only gave a positive results. Still the pattern of monoclonal expression in the stained cases varies. Our results suggest a possible role that may be mediated by the cellular immune reaction in the pathomechanism of such disease. 


\section{4}

HISTOPATHOLOGIC AND IMMUNOHISTOPATHOLOGIC etc...

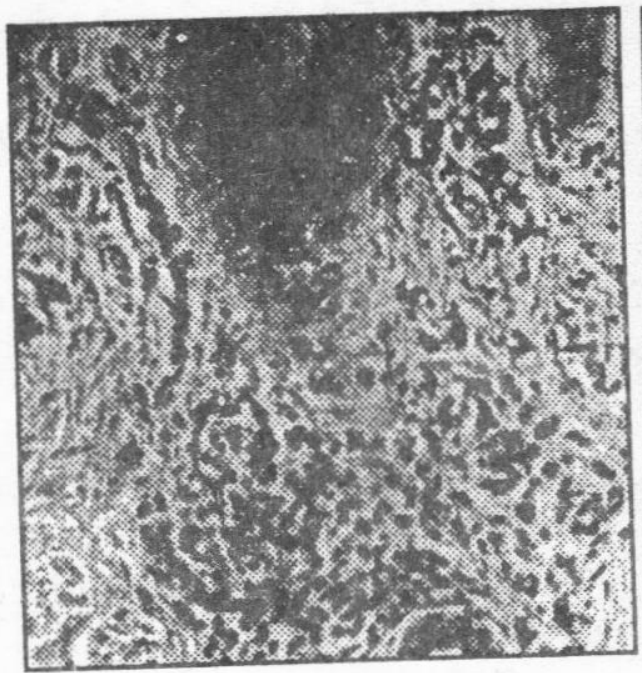

Fig.1 - Skin biopsy showiing upper dermal perivaseular round cellular infiltrate, Hx. \& E. x 150.

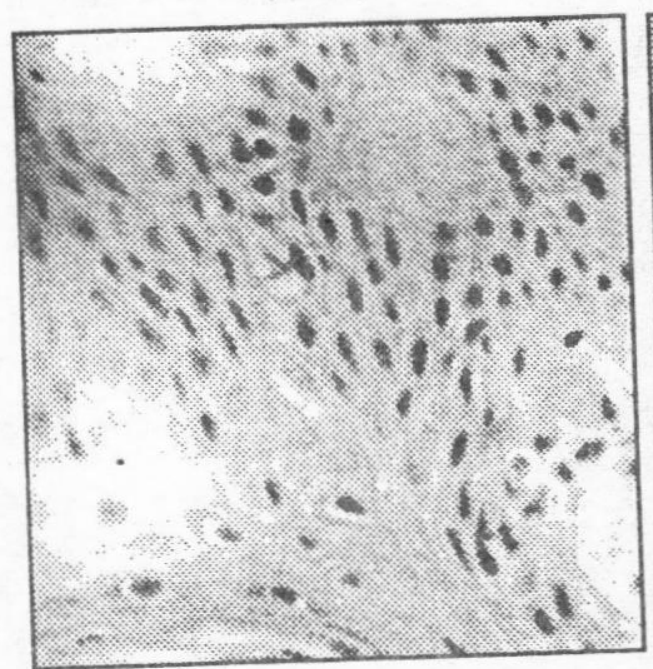

Fig. 2 - Skin biopsy srlowing hyperkceratosis, mild parakeratosis together with marked spongiosis and acanthosis, Hx. \& E. x 300.

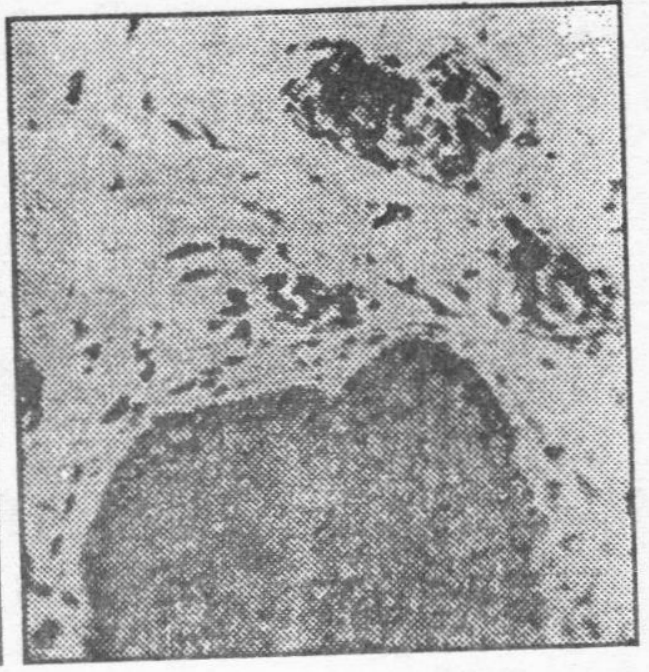

Fig. 3 - Skin biopsy showing upper dermal, perivascular accumulation of macrophages . + ve Mac 387 stain $\times 150$.

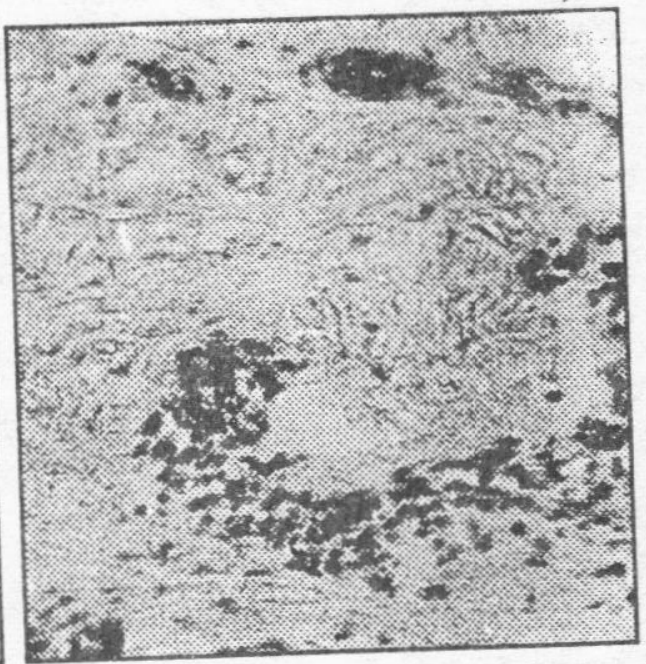

Fig. 4 - Skin biopsy showing upper dermal accumulatio of Bcells . +ve MB2 stain $\times 150$.

Volume 21, 1991 


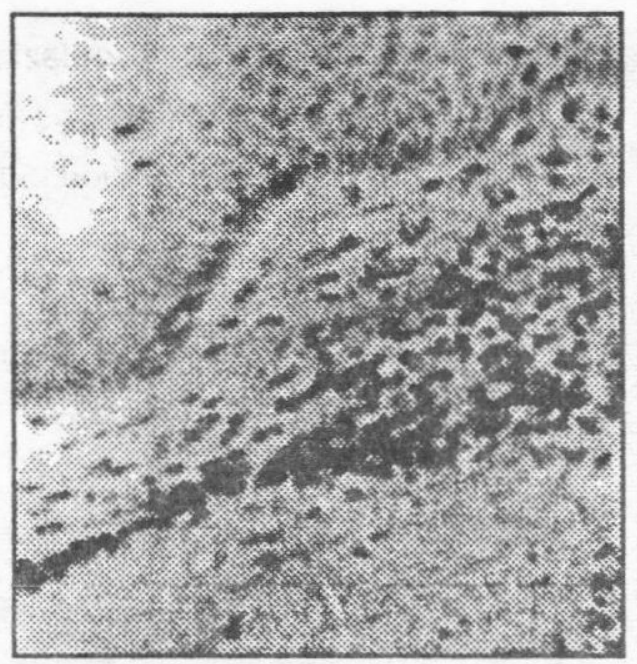

Fig.5 - skin biopsy shwing upper dermal accumulation of $T \& B$ ceells. + ve MT2 stain $\times 150$.

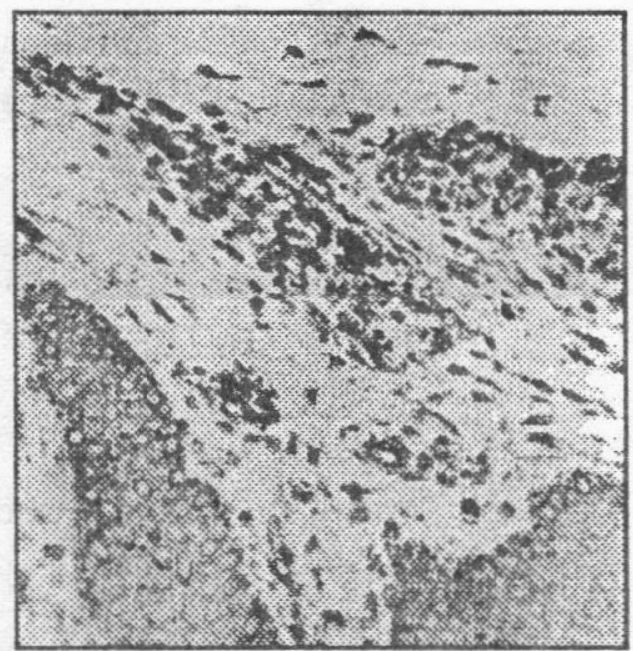

Fig.6 - Skin biopsy showing upper dermal accwnlation of $B$ - cells and histiocytes. + ve LN2 stain $x$ 150 .

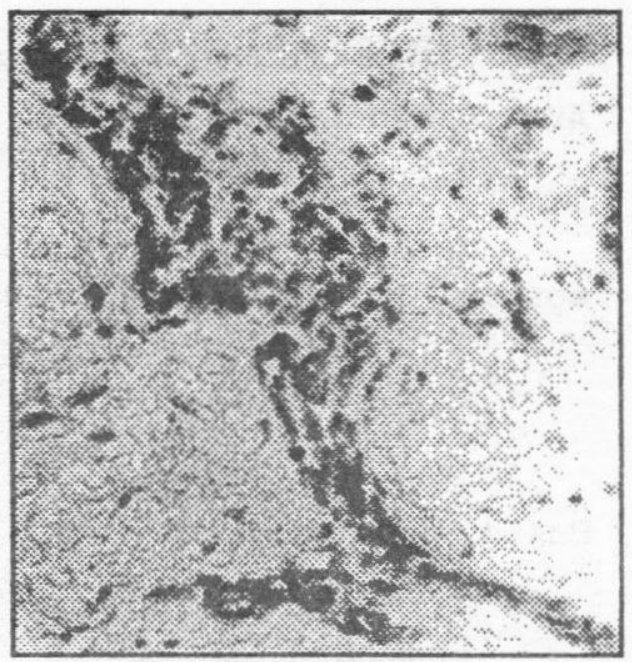

Fig.7 - Skin biopsy showing upper dermal accumulation of all iymphoytes and macrophages. + ve LC stain $\times 150$. 


\section{REFERENCES}

Aiba, S. and Tagami, H. (1985) :

Arch. Dermatol 121: 761.
Naiem, M. J.; Gerdes, J.; Abdulaziz, Z. and Stein, H. (1982): J. of Immunological method 50145.

Aoshima, J.; Komura, J and Of uji,

S. (1981) : Dermatologica, 162: 64

Panizzon, R. and Bloch, P. (1982): Dermatologica, $165: 551$.

Bos, J.; Huisman, P. and Krieg, S. Parsons, J. (1986): J. Am. Acad. Der(1985) : Acta. Dermatol. Vematol. 15:159.

nereol. 65: 132

Patterson, J. and Edelson, R. (1983): J. cutan Pathol . 10: 540.

M. and Mabrouk, D. (1987):

Int. J. Dermatol. $26: 237$

Sugiura, H.; Miyauchi, $H$. and Uehara, M. (1988) : Arch. Dermatol. $280: 405$.

othy, B. ( 1982 ): J. Invest . Dermatol 78: 323

Takaki, Y.; Koshiyama, Y. and Watanabe, S. (1977): J. Dermatol ., 4: 37 .

Mobacken, H.; B jursten, L. and LOwhagen, G. (1983): Arch.

Vieria, L.; Colley, D.; Souza, C. and Gazzinelli, G. (1987): J. InDermatol . 275: 92 vest. Dermatol., 83: 210. 
"1

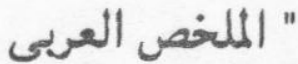

تقييم مرض النخاليه الوردى باثولوجيا ومناعيا

$$
\begin{aligned}
& \text { / / توكل جميل عزمى عبد الحميد } \\
& \text { قسم الباثولوجيا - طب المنصورة }
\end{aligned}
$$

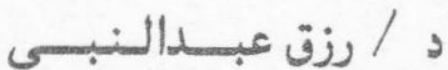

$$
\begin{aligned}
& \text { قسم البلدبة - طب المنصورة }
\end{aligned}
$$

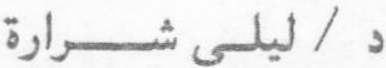

$$
\begin{aligned}
& \text { قسم الجلدية - طب الازهر }
\end{aligned}
$$

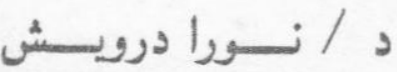

$$
\begin{aligned}
& \text { قسم الجلدية - طب المنصورة }
\end{aligned}
$$

أجريت دراسة توضيح خلايا الالتهابات فى ·† حالة من مرضى النخالية الوردى عن طريق أخذ عينات باثولوجى من هؤلاء المرضى وصباغتها بالهييا توكسلين والايوسين وباستخدام طريقة البيروكسيديز المناعى الفير مباشر بعد تثبيت هذه العينات فى مادة ب ه والميثانول وغمرها فى البرافين ـ بالرغم من أن با حاله نقط أعطت نتائج إيجابية وهذه النتائج كانت مختلفة فى جميع المالات الموجبه الا ان هذه الدراسة تشير الى وجود مشاركة من المناعة الملوية فى التفاعل المناعى لهذا المرض . لماعل 
